\title{
Performance of Entrepreneurs and Enterprise Involvement Runs by Women Self Help Groups in Madurai, Ramnad and Dindigul Districts of Tamil Nadu - A Study
}

\section{Selvaraj $\mathbf{N}^{*}$}

Department of Commerce, Saraswathi Narayanan College, Madurai, Tamilnadu, India

\begin{abstract}
Entrepreneurs compete in rapidly changing markets and must respond to the challenges of globalization technological advance and other factors. The contribution of women to the process of development is widely accepted. The concept of women as entrepreneurs is becoming a global phenomenon. Today, all over the world, women play a vital role in the business community. The need of Self help groups growing day by day. Almost $75 \%$ of the Madurai, Ramnad and Dindigul population depends on Agriculture. The technologies involved in Agriculture are eventually growing. Self Help Groups (SHGs) or Thrift and Credit groups are mostly informal groups whose members' pool savings and relent within the group on rotational or needs basis. These groups have a common perception of need and impulse towards collective action. Involvement of SHGs with banks could help in overcoming the problem of high transaction costs in providing credit to the poor, by passing on some banking responsibilities regarding loan appraisal, follow-up and recovery etc., to the poor themselves. The Fisher's Discriminant Function Analysis test was applied to analyse the interest of the independent variables which discriminate the two groups' namely good performers vs. poor performers in the present study.
\end{abstract}

Keywords: Performance; Entrepreneurs; Micro-enterprise; Involvement; Discriminate

\section{Introduction}

Entrepreneurs compete in rapidly changing markets and must respond to the challenges of globalization, technological advance and other factors. Micro enterprise has limited resources at its disposal while competing with giant enterprises.

In most developing countries, even today women deny themselves to their legitimate position, ignore the resources of their own growth and continue to live for others. In this context, if women are encouraged to become entrepreneurs who are economically sound, it will help them to stand on their own legs, while living for their children and family [1].

The contribution of women to the process of development is widely accepted. The concept of women as entrepreneurs is becoming a global phenomenon. Today, all over the world, women play a vital role in the business community. Women are trying to discard the yoke of feminity imposed by men and create their own identity. More and more Indian women are joining the media for holding strong views of their profession and role in the Society.

The need of Self help groups growing day by day. Almost $75 \%$ of the Madurai, Ramnad and Dindigul population depends on Agriculture. The technologies involved in Agriculture are eventually growing. But despite of that, the per capita income growth of the individual especially farmers of low-income groups, leads to poverty and thereby reduces the nominal income. To overcome the sufferings due to poverty, it is becoming mandatory to encourage clusters or self help group. The Self Help Group can promote their capability efficiency and thereby increasing their individual status in economical and social attributes.

Self Help Groups (SHGs) or Thrift and Credit groups are mostly informal groups whose members' pool savings and relent within the group on rotational or needs basis. These groups have a common perception of need and impulse towards collective action. Many of these groups got formed around specific production activity, promoted savings among members and use the pooled resources to meet the emergent needs of members, including consumption needs. Sometimes, the internal savings generated were supplemented by external resources loaned/donated by the Voluntary agency, which promoted the SHGs. Since SHGs were able to mobilize savings from the poor who were not expected to have any savings and could also recycle effectively the pooled savings among members, they succeeded in performing/ provided banking services to their members, may be in a primitive way, but in a manner which was cost effective, simple, flexible at the door step of the members and above all without any defaults in repayment by borrowers [2].

Involvement of SHGs with banks could help in overcoming the problem of high transaction costs in providing credit to the poor, by passing on some banking responsibilities regarding loan appraisal, follow-up and recovery etc., to the poor themselves. In addition, the character of SHGs and their relations with members offered ways of overcoming the problem of collateral, excessive documentation and physical access, which reduced the capacity of formal institutions to serve the poor $[3,4]$.

Based on local conditions and requirements, the SHGs have involved their own methods of working. An SHG is an informal association of women, preferably belonging to the same economic class who has come forward voluntarily to work for their own economic, social and democratic development.

*Corresponding author: Selvaraj N, Assistant Professor of Commerce, Saraswathi Narayanan College, Madurai, Tamilnadu, India, Tel: 09843727975 E-mail: selvaraj_narayanan@yahoo.com

Received November 09, 2015; Accepted March 11, 2016; Published March18, 2016

Citation: Selvaraj N (2016) Performance of Entrepreneurs and Enterprise Involvement Runs by Women Self Help Groups in Madurai, Ramnad and Dindigu Districts of Tamil Nadu - A Study. J Account Mark 5: 163. doi:10.4172/21689601.1000163

Copyright: (C) 2016 Selvaraj N. This is an open-access article distributed under the terms of the Creative Commons Attribution License, which permits unrestricted use, distribution, and reproduction in any medium, provided the original author and source are credited. 
Over centuries, Women in India have become a neglected lot. Although women enjoyed a pride of place in the earlier days, overtime, they become overburdened with an overdose of children and gross under nourishment. Relegated to do all household chores, while also distributing to the family income, they were denied access to formation, education and involvement in decision making. They underwent many untold sufferings, both physical and mental. They virtually had no role in shaping the society and their true potential remained unrecognized [5].

The dowry system, though legally abolished, continues to survive, degrading women to an unwanted but tradable commodity and becoming a permanent source of harassment of women for life in certain households. Widows face similar harassment. Re-marriage does not offer a solution, as women continue to be treated with doubt and suspicion or at best as an unpaid maid servant. The worst to suffer are the female headed households, who by virtue of being illiterate are pushed to becoming the poorest of the poor, becoming an object of ridicule and totally neglected by the society, with no one ever coming forward to safeguard them [6]

\section{Statement of the problem}

A self-help group (SHG) is a voluntary association of people with common goal. The concept of 'Self Help Group' appears to be a good alternative strategy to involve people in the development process. In these circumstances it is felt important and necessary to study the performance of women entrepreneurs.

Hence, the present study is undertaken to analyse the performance of women entrepreneurs for Madurai, Ramnad and Dindigul districts of Tamil Nadu.

\section{Period of study}

The field survey was conducted from September 2014 to March 2015 for the collection of primary data. The reference period of the survey was 2014-2015.

\section{Objectives of the Study}

The basic objectives of the study have the performance of women entrepreneurs.

\section{Sampling Design}

For the purpose of primary data collection, three districts namely Madurai, Ramnad and Dindigul have been selected the main reason for selecting these districts is that the former are a developed district, the middle is backward one and the last is developing district. Out of the total of 450 sample women Micro entrepreneurs each 150 from the districts were randomly selected from SHGs functioning under NGOs and Mahilar Thittam Schemes in each block of three districts by using proportionate sample method.

\section{Discriminant Function Analysis}

The Fisher's Discriminant Function Analysis test was applied to analyse the interest of the independent variables which discriminate the two groups' namely good performers vs. poor performers in the present study.

$$
\begin{aligned}
& z=\sum_{\substack{i=1 \\
\text { Where, }}}^{\mathrm{n}} \mathrm{LiXi} \\
& \qquad \mathrm{Z}=\text { Total Discriminant score } \\
& \quad \mathrm{X}_{1 \ldots} \mathrm{X}_{\mathrm{n}}=\text { Discriminant variables }
\end{aligned}
$$

$$
\begin{aligned}
& L_{1} \ldots L_{n}=\text { Linear Discriminant coefficient } \\
& N=\text { Number of variables }
\end{aligned}
$$

\section{Performance of Women Entrepreneurs and Enterprise Involvement}

The entrepreneurs are classified into good and poor performer on the basis of average return on investment. The average return on investment was 9.20 per cent, 8.85 per cent and 9.35 per cent for Madurai, Ramnad and Dindigul district respectively [7]. The good performers are those who secured the percentage above the average return on investment and the poor performer are those who secured the percentage below the average return on investment of each district. It indicates that among the three districts, the performance of women micro entrepreneurs was found better in Dindigul district than other two districts. In case of Madurai district 104 (69.33 per cent) and 46 (30.67 per cent) are good and poor performance respectively. In Ramnad district out of 150 , 98 (65.33 per cent) and 52 (34.67 per cent) fall under the category of good and poor performance respectively. In Dindigul district, out of 150 respondents, 108 (72 per cent) come under the category of good performance and remaining 42 (28 per cent) belong to the category of poor performance [8]. The enterprise involvement is highly essential for the performance of the enterprise and the performance also acts as a motivator to enterprise involvement among the entrepreneurs. There is a cyclical relationship between these two aspects. In order to analyze the association between the performance of the entrepreneur and their enterprise involvement, the mean score of each enterprise involvement variable is calculated. The ' $z$ ' statistics were also computed to find out the significant difference between different groups of entrepreneurs. The resultant mean score of the enterprise variables and their related ' $\mathrm{z}$ ' statistics are presented in Table 1.

Table 1 shows that in the case of women entrepreneurs in Madurai district, the most involvement enterprising aspects among the good performers are major decisions and help during setting up stage, as the mean scores are 3.8116 and 3.5216 respectively. The mean scores of overall involvement among them are 3.1543 and 2.3802 respectively. The significant differences among the good and poor performers are noticed in a few enterprise involvement variables namely source of inspiration, help during setting up stage, major decisions and membership, since their ' $z$ ' statistics are significant at 5 per cent level. Enterprise involvement variable among women entrepreneurs in Ramnad district are shown in Table 2.

Table 2 shows that in the case of women entrepreneurs in Ramnad district, the future plans and membership are the important variables among the good performers in the most involvement aspects for enterprising its mean score are 3.9332 and 3.7911 respectively. The mean scores of overall involvement among them are 3.4047 and 2.5423 respectively. The significant differences among the good and poor performers are noticed in a few enterprise involvement variables namely source of inspiration, help during setting up stage, managing various functions, time spent on unit related work, pride in being an entrepreneur and future plans, since their ' $\mathrm{z}$ ' statistics are significant at 5 per cent level.

Enterprise involvement variable among women entrepreneurs in Dindigul district are shown in Table 3.

Table 3 shows that in the case of women entrepreneurs in Dindigul, the most involvement enterprising aspects among the good and poor performers are future plans, Bride in being entrepreneurs since their mean scores are 3.9421 and 3.8122 respectively. The mean 
Citation: Selvaraj N (2016) Performance of Entrepreneurs and Enterprise Involvement Runs by Women Self Help Groups in Madurai, Ramnad and Dindigul Districts of Tamil Nadu - A Study. J Account Mark 5: 163. doi:10.4172/2168-9601.1000163

Page 3 of 5

\begin{tabular}{|c|c|c|c|c|}
\hline \multirow{2}{*}{ SI. No. } & \multirow{2}{*}{ Enterprise involvement variable } & \multicolumn{2}{|c|}{ Average score } & \multirow{2}{*}{ 'z' Statistics } \\
\hline & & Good performer & Poor performer & \\
\hline 1. & Source of inspiration & 3.0415 & 1.8816 & $2.6629^{*}$ \\
\hline 2. & Help during setting up stage & 3.5216 & 3.1762 & $1.2431^{*}$ \\
\hline 3. & Managing various functions & 3.2436 & 1.7261 & 1.5541 \\
\hline 4. & Major decisions & 3.8116 & 1.8915 & $2.1124^{*}$ \\
\hline 5. & Time spent on unit related work & 3.6621 & 2.5861 & 0.8261 \\
\hline 6. & Satisfaction & 3.4661 & 2.9810 & 0.6621 \\
\hline 7. & Training & 2.5311 & 2.5314 & 0.7633 \\
\hline 8. & Pride in being an entrepreneur & 3.5421 & 1.9945 & 1.4628 \\
\hline 9. & Membership & 2.5612 & 3.1421 & $1.6575^{*}$ \\
\hline \multirow[t]{2}{*}{10.} & Future plans & 2.1621 & 1.8911 & 0.5538 \\
\hline & Overall involvement & 3.1543 & 2.3802 & $1.7361^{*}$ \\
\hline
\end{tabular}

Table 1: Enterprise involvement among women entrepreneurs in Madurai district.

\begin{tabular}{|c|c|c|c|}
\hline \multirow{2}{*}{ S. No. } & enterprise involvement variable & \multicolumn{2}{|c|}{ Average score } \\
\cline { 3 - 4 } & Source of inspiration & Good performer & Poor performer \\
\hline 1. & Help during setting up stage & 3.3324 & 1.9821 \\
\hline 2. & Managing various functions & 2.722 & 3.2861 \\
\hline 3. & Major decisions & 3.5215 & 1.9261 \\
\hline 4. & Time spent on unit related work & 2.9691 & 1.9816 \\
\hline 5. & Satisfaction & 3.5715 & 2.7921 \\
\hline 6. & Training & 3.6924 & 3.1924 \\
\hline 7. & Pride in being an entrepreneur & 2.7621 & 2.7562 \\
\hline 8. & Membership & 3.7215 & 2.1822 \\
\hline 9. & Future plans & 3.7911 & 3.3321 \\
\hline 10. & Overall involvement & 3.9332 & 1.9921 \\
\hline
\end{tabular}

Table 2: Enterprise involvement among entrepreneurs in Ramnad district.

\begin{tabular}{|c|c|c|c|c|}
\hline \multirow{2}{*}{ S. No. } & \multirow{2}{*}{ Enterprise Involvement Variable } & \multicolumn{2}{|c|}{ Average Score } & \multirow{2}{*}{ 'z' Statistics } \\
\hline & & Good Performer & Poor Performer & \\
\hline 1. & Source of inspiration & 3.3516 & 1.9921 & $2.8516^{\star}$ \\
\hline 2. & Help during setting up stage & 2.7821 & 3.2961 & 1.5911 \\
\hline 3. & Managing various functions & 3.5422 & 1.9362 & 2.2215 \\
\hline 4. & Major decisions & 2.9761 & 1.9961 & $3.1516^{*}$ \\
\hline 5. & Time spent on unit related work & 3.5861 & 2.7811 & 1.9921 \\
\hline 6. & Satisfaction & 3.7162 & 3.1924 & $3.6415^{*}$ \\
\hline 7. & Training & 2.7821 & 2.7621 & 0.7915 \\
\hline 8. & Pride in being an entrepreneur & 3.8122 & 2.1922 & $2.6621^{*}$ \\
\hline 9. & Membership & 3.7516 & 3.3542 & 0.4516 \\
\hline \multirow[t]{2}{*}{10.} & Future plans & 3.9421 & 1.9982 & 2.9122 \\
\hline & Overall involvement & 3.4242 & 2.5501 & $1.9921^{*}$ \\
\hline
\end{tabular}

Table 3: Enterprise involvement among entrepreneurs in Dindigul district.

scores of overall involvement among them are 3.4242 and 2.5501 respectively. The significant differences among the good and poor performers are noticed in a few enterprise involvement variables namely source of inspiration, help during setting up stage, managing various functions, time spent on unit related work, pride in being an entrepreneur and future plans, since their ' $z$ ' statistics are significant at 5 per cent level.

\section{Enterprise Involvement Index}

The ten enterprise involvement variables are rated on a 5 point scale among the entrepreneurs as 5, 4, 3, 2 and 1 marks according to their

nature of involvement.
Enterprise Involvement Index $=\frac{\sum_{i=1}^{n} \text { EISi }}{\sum_{i=1}^{n} \text { MEISi }} \times 100$

EIS $=$ Enterprise Involvement Score

MEIS = Maximum Enterprise involvement score

$\mathrm{n}=$ Number of enterprise involvement variables.

In the above formula, the sum of scores obtained by the women 
entrepreneurs from all the ten variables and the related sum of maximum score of all enterprises involvement variables are used to find out the enterprise involvement index (EII) [9].

The Enterprise Involvement Index (EII) is prepared to estimate the overall performance of the entrepreneur regarding their enterprise involvement index, EII is calculated by using formula 2 in the present study, the EII is classified as less than 20,20 to 40, 40 to 60, 60 to 80 and 80 and above. The distribution of entrepreneurs regarding their EII in Madurai district is shown in Table 4.

Table 4 reveals that in the case of women entrepreneurs in Madurai district, out of 150 total women entrepreneurs, maximum of $51(34.00$ per cent) of them have EII of 40 to 60 , followed by 46 (27.33) of them have EII of 20 to 40, 26 (17.33 per cent) of them have EII of 60 to 80, 23 (15.33 per cent) have less than 20 and 9 (6.00) of them have EII of 80 and above. Among the good performers, the number of entrepreneurs who have an EII of less than 40 constitute 54 whereas among poor performers there are 10 (10.22 per cent) to the respective total. At the same time the number of good performers who have EII of above 60 Constitute 23 (22.11 per cent) whereas among the poor performers they constitute 12 (26.09 per cent) to the respective total.

Enterprise involvement index among women entrepreneurs in Ramnad district are shown in Table 5.

Table 5 reveals that in the case of women entrepreneurs in Ramnad district, out of 150 total entrepreneurs, maximum of 63 (42.00) of them have EII of 20 to 40, followed by 37 (24.67) of them have EII of Less than 20. The number of entrepreneur who have more than 80 as EII constitute 8 (5.33) to the total. Among the good performers, the number of entrepreneurs who have an EII of less than 40 constitute 61 (62.25) whereas among poor performers there are 39 ( 94.98 per cent) to the respective total. At the same time the number of good performers who have EII of above 60 Constitute 6 (16.32 per cent) whereas among the poor performers they constitute 8 (15.39 per cent) to the respective total.

Enterprise involvement index among women entrepreneurs in Dindigul district are shown in Table 6.
Table 6 reveals that in the case of women entrepreneurs in Dindigul district, out of 150 total entrepreneurs, maximum of 58 (38.67 per cent) of them have EII of 40 to 60 , followed by 39 ( 26.00 per cent) of them have EII of 60 to 80, 27 (18.00 per cent) of them have EII of 20 to 40, and 13 (8.67 per cent) less than 20 per cent and above 80. Among the good performers, the number of entrepreneurs who have an EII of less than 40 constitute 24 (22.22) whereas among poor performers there are 16 (38.09 per cent) to the respective total. At the same time the number of good performers who have EII of above 60 constitute 36 (33.33 per cent) whereas among the poor performers they constitute 16 (38.10 per cent) to the respective total.

\section{Summary of Findings}

In Madurai district the good and poor performers significantly differ in few enterprise involvement aspects namely source of inspiration, help in setting up stage, major decisions, membership and the overall involvement.

In Ramnad district the good and poor performers significantly differ in a few enterprise involvement aspects namely sources of inspiration, help in setting up stage, managing various functions, time spent on unit related work pride in being an entrepreneur, future plans and the overall involvement.

In Dindigul district, the good and poor performers significantly differ in a few enterprises involvement aspects namely sources of inspiration, major decisions, satisfaction, Pride in being an entrepreneur and overall involvement.

\section{Suggestions}

The participation of women in the economic activities is necessary for raising the status of women in the society. It becomes imperative for the Government to frame policies providing those rights, role and opportunities for their betterment. The Government of India has taken the lead role including women into various avenues of economic activity like employment in the organized sector, Micro SHG movement, and Entrepreneurship promotion by framing certain special policies. The

\begin{tabular}{|c|c|c|c|c|}
\hline \multirow{2}{*}{ S. No. } & \multirow{2}{*}{ Enterprise Involvement Index (percentage) } & \multicolumn{2}{|c|}{ Number of Women Entrepreneurs } & \multirow{2}{*}{ Total } \\
\hline & & Good Performer & Poor Performer & \\
\hline 1. & Less than 20 & $19(18.27)$ & $4(8.20)$ & $23(15.33)$ \\
\hline 2. & $20-40$ & $35(33.66)$ & $16(13.04)$ & $41(27.33)$ \\
\hline 3. & $40-60$ & $27(25.96)$ & $24(52.17)$ & $51(34.00)$ \\
\hline 4. & $60-80$ & $17(16.35)$ & $9(19.52)$ & $26(17.33)$ \\
\hline \multirow[t]{2}{*}{5.} & 80 and above & $6(5.76)$ & $3(6.32)$ & $9(6.00)$ \\
\hline & Total & $104(100.00)$ & $46(100.00)$ & $150(100.00)$ \\
\hline
\end{tabular}

Table 4: Enterprise involvement among entrepreneurs in Madurai district.

\begin{tabular}{|c|c|c|c|c|}
\hline \multirow{2}{*}{ S. No. } & \multirow{2}{*}{$\begin{array}{l}\text { Enterprise Involvement Index } \\
\text { (percentage) }\end{array}$} & \multicolumn{2}{|c|}{ Number of Women Entrepreneurs } & \multirow{2}{*}{ Total } \\
\hline & & Good Performer & Poor Performer & \\
\hline 1. & Less than 20 & $20(20.41)$ & $17(32.64)$ & $37(24.67)$ \\
\hline 2. & $20-40$ & $41(41.84)$ & $22(42.31)$ & $63(42.00)$ \\
\hline 3. & $40-60$ & $21(21.43)$ & $5(9.62)$ & $26(17.33)$ \\
\hline 4. & $60-80$ & $10(10.20)$ & $6(11.54)$ & $16(10.67)$ \\
\hline \multirow[t]{2}{*}{5.} & 80 and above & $6(6.12)$ & $2(3.85)$ & $8(53.33)$ \\
\hline & Total & $98(100.00)$ & $52(100.00)$ & $150(100.00)$ \\
\hline
\end{tabular}

Table 5: Enterprise involvement among entrepreneurs in Ramnad district. 
Citation: Selvaraj N (2016) Performance of Entrepreneurs and Enterprise Involvement Runs by Women Self Help Groups in Madurai, Ramnad and Dindigul Districts of Tamil Nadu - A Study. J Account Mark 5: 163. doi:10.4172/2168-9601.1000163

Page 5 of 5

\begin{tabular}{|c|c|c|c|c|}
\hline \multirow[t]{2}{*}{ S. No. } & \multirow{2}{*}{$\begin{array}{c}\text { Enterprise } \\
\text { Involvement Index } \\
\text { (percentage) }\end{array}$} & \multicolumn{2}{|c|}{$\begin{array}{l}\text { Number of Women } \\
\text { Entrepreneurs }\end{array}$} & \multirow[t]{2}{*}{ Total } \\
\hline & & Good Performer & Poor Performer & \\
\hline 1. & Less than 20 & $9(8.33)$ & $4(9.52)$ & $13(8.67)$ \\
\hline 2. & $20-40$ & $15(13.89)$ & $12(28.57)$ & $27(18.6)$ \\
\hline 3. & $40-60$ & $48(44.44)$ & $10(23.81)$ & $58(38.67)$ \\
\hline 4. & $60-80$ & $29(26.85)$ & $10(23.81)$ & $39(26.00)$ \\
\hline \multirow[t]{2}{*}{5.} & 80 and above & $7(6.48)$ & $6(14.29)$ & $13(8.67)$ \\
\hline & Total & $108(100.00)$ & $42(100.00)$ & $150(100.00)$ \\
\hline
\end{tabular}

Table 6: Enterprise involvement among entrepreneurs in Dindigul district.

Government has also and set up some Institutions to render necessary assistance to the development of women entrepreneurs according to the needs of women entrepreneurs, which were evaluated by the Government. In order to ascertain how far these needs are being met by the existing institutions, in this context, the following suggestions are made.

\section{References}

1. Asha Das (1998) Statement to the Commission on the Status of Women. Department of Women and Child Development, India.

2. Madhumurthy K (2002) Entrepreneur: Evaluation of the Concept and Characteristics SEDME.

3. Ambigadevi $P(2003)$ Share of Women in total family Income -A two Group Discriminate Analysis. Asian Economic Review 45: 373-378.

4. Edgcomb EL, Klein JA, Thetford T (2007) Pursuing Sustainability in the Micro Enterprise Field: Findings from a literature review by Field. The Aspen Institute, USA.

5. Ismail, Ghafar A, Condro M, Widiyanto (2008) Sustainability of BMT financing for Developing Micro-enterprises.

6. Mythili S (2003) Women Entrepreneurs, A New Social Order. HRD Times

7. Sheriff RL (2008) Micro Enterprises give California's Economy a Boost Policy Briefs.

8. Ayyagari MT, Beck, Demirguc-Kunt A (2003) Small and medium enterprises across the globe: A new database. World Bank Policy Research Working Paper.

9. Foti R, Mlambo N, Muringai V, Mavunganidze Z, Mapiye C (2007) Heterogeneity among Zimbabwe's Rural Micro Enterprises and the Determinants of their inclination to agro-dealership. African Journal of Business Management. 